\title{
Playing the Identity Card: \\ Stereotypes in European Football
}

\begin{abstract}
$\underline{\text { Abstract }}$
The amount of space ‘quality' newspapers devote to football reflects its increasing importance in European culture. European print media discourse on football does more than cover the game's technicalities, though; it also shapes its readers' awareness of national identities. It is the aim of this study to analyse football match reports and articles from Britain, Spain, France and Germany with a view to understanding the mechanisms at work in the construction of national stereotypes. The language used by these articles is varied, entertaining, highly inventive and often provocative, evoking references to warfare, politics, history, economics and popular culture. In many cases, the principal elements of the stereotypes represented by the European press are the same from country to country (English fighting spirit, Spanish toughness, French flair, German efficiency). European print media discourse on football may, therefore, be said to reinforce myths of national character and strengthen notions of collective identity associated with sport.
\end{abstract}




\section{Playing the Identity Card: Stereotypes in European Football}

Sport is an increasingly important socio-economic phenomenon in Europe. Football, in particular, is commanding ever more attention and this is, in part, reflected by the amount of space devoted to it by European 'quality' newspapers. When European newspapers report on football, however, they do more than merely give accounts of the game's technicalities. Indeed, European print media discourse on football may be said to shape, if not manipulate, its readers' awareness of, amongst other things, the perceived national characteristics of the countries of Europe. In what ways, then, do the vocabulary and images employed by European football writing contribute to the construction of national stereotypes? What are the principal elements of such stereotypes? Most importantly, are perceptions of national character as mediated by the press the same from country to country?

The present article provides a snapshot of a much broader research project analysing the construction of national, regional and group identities in the sports media of Europe's most dominant football countries. It offers initial empirical findings that are related to a broader interpretative and conceptual framework which will be further developed in subsequent work. ${ }^{1}$ It is the twin aim of this study, then, to examine newspaper articles and football match reports to gain a preliminary understanding of the mechanisms at work in sports media reflexions of national identity in England, Spain, France and Germany ${ }^{2}$ and to stimulate further debate about them. To permit effective comparisons, the newspapers analysed are all 'quality' dailies. In England, we studied The Times, the right of centre daily tracing its ancestry to the eighteenth century. In Spain, the newspapers examined are $\underline{A B C}, a$ historically right-wing, tabloid size daily and El País, a left of centre publication generally considered to bias Spain's socialist government in office from 1982 to 1996. The French newspapers considered are Le Monde, a left of centre daily founded in 1944 appealing to the educated élite of French society and the slightly more popular Libération founded in 1973. Lastly, the Süddeutsche Zeitung is Germany's best known liberal daily. Admittedly, different political biases operate in these newspapers and our findings must be read with some caution in this light. A research opportunity 
awaits, for instance, for a comparative study of media sports texts produced by, say, two newspapers from the same country but of opposing political convictions. The number of papers studied here (and their political orientation) may vary, then, but the amount of column inches analysed is approximately the same from country to country ensuring that the sample sizes from each country were roughly equal. Finally, to provide a compact chronological focus for the work, the data studied were all drawn from press reports on the one competition: the European Championship finals held in England in June and July 1996.

Before analysing the data, though, a number of theoretical considerations must be examined. First, football writing is an important element of print media discourse. As the socio-economic importance of what is already the world's most popular sport increases, it becomes ever more unthinkable that a publication claiming the title 'newspaper' could survive commercially without successful coverage of sport in general and football in particular. Moreover, the language employed by journalists in this section of the press is worthy of attention given that, as Hopcraft says, it 'has developed into a distinctive style [to] become ... an entertainment in its own right.' Hopcraft, himself a football journalist, asserts that 'While football matches are sometimes dull, sports pages can never afford to be. ${ }^{4}$ Media sport is, in other words, a valuable consumer commodity which has to be packaged in an attractive and therefore marketable linguistic form which, partially at least, accounts for the highly imaginative and inventive metaphors employed by European football writing examples of which were examined by the present authors in a previous study. ${ }^{5}$ The metaphorical descriptions and emotive vocabulary of football writing, though, are not merely ingenious stylistic devices affording attractive literary qualities to the prose in question. As Blain and Boyle note, sport is 'a major economic phenomenon as well as a cultural and political one ${ }^{6}$ which is primarily consumed through the media. As such, media sport communicates information not just about itself but about culture as a whole. In short, when we read, say, a press report on a football match involving the French national team, we receive and process information about, inter alia, concepts of Frenchness itself. Football is, then, appropriated to communicate information about national identity. It becomes 'indexical ${ }^{7}$ in that it can be used to represent perceived national characteristics about which it apparently presents direct evidence. As Blain and Boyle state: 'The way in which sport is written about ... becomes a source of information about our beliefs, opinions and attitudes as cultures. ${ }^{8}$ An integral element 
of these beliefs is, of course, a sense of our own collective national identity and an awareness of other nations' supposed characteristics. Indeed, the rôle played by media representations of sport in the construction of national identities cannot be overestimated. This 'culture of nationality' is developed, shaped, even inculcated by the media which, therefore, contribute to the maintenance of a set of shared cultural values which serve to reinforce a consensual perception of national unity. One key function of media sport texts is, then, ideological, 'to win the consent of the people to a shared image of the nation and identity'. ${ }^{10}$ One of the ways in which European football writing achieves this is through the stereotypification of the characters, the footballers, pitted against each other in an unfolding narrative, the article, recounting a moment of crisis and conflict, the match itself. As we shall see, these stereotypes which are, in Higson's terms, 'recognisable and well accepted conventions of representation ${ }^{11}$ in that they resonate in other forms of culture, too, e.g. cinema and literature, operate in two interdependent ways. First, they provide a shorthand definition of the nation in terms of its own history and society and, second, they offer an insight into how the nation may be perceived as different from other nations. Stereotypes are also iterative, that is repeated from text to text, which further reinforces European myths of national identity. Stereotypes of national identity, for all their conventional, reductionist qualities, are rooted in objective realities. They are founded upon events or developments in political, cultural, socio-economic and military domains. Throughout this discussion, then, we shall attempt to highlight some of the origins of the stereotypes and images in question. It is our contention that this 'discursive paralysis we call stereotypification'12 operates through football writing in all four countries studied rather than in England alone and that, consequently, notions of national identity tend to be continually evoked across the European continent. What we attempt in the present study is to isolate and describe these notions in Blain, Boyle and O'Donnell's terms of 'autotypification' (here how Europe's dominant football nations perceive themselves) and 'heterotypification' (how nations are perceived by others). ${ }^{13}$ Ultimately, through these analyses, we hope to discover the extent to which notions of collective national identity remain integral to European football writing in particular and central to that of which the latter is undoubtedly an extension: European culture in general. 


\section{National Representation in British Football Writing}

The overriding theme of the British press reports of the England football team is that of combat with the supposedly typically English sporting virtues of commitment, energy, and, above all, fighting spirit being highly valued by the media discourse studied. Mangan has noted the importance of warfare in British culture and asserts that 'War, symbolised in the metaphors of war used so widely and so frequently, is deeply embedded in our institutions, thinking, recreations' ${ }^{14}$ In the days of the British Empire war was regarded almost as a national duty; it was the instrument by which 'superior' British values were exported around the world. It required of its participants patriotism, disciplined aggression, courage, leadership qualities, physical strength and self-sacrifice. These virtues were extolled in the prose, poetry and painting of the Victorian and Edwardian era. A culturally endorsed ideal of manhood developed, then, and grew into a 'martial mythology of masculinity' ${ }^{15}$ Of great importance here is the rôle played by sport in the propagation of this ideological warrior ethos. Mangan notes the parallels drawn in the British culture of a century or so ago between the qualities demanded of the colonial soldier and the virtues acquired through sport. The bond between the two was so great that war itself came to be portrayed as a sport in which 'colonial battlefields [became] exotic versions of the playing fields of Eton'. ${ }^{16}$ In latter day football writing, the parallels between sport and a militaristic mode of thinking, which might be considered the legacy of the imperial era, are still active with the result that the discourse of football is imbued with military metaphors and references which, thereby, connect football with a broader sociocultural and historically determined perception of a typically aggressive and virile form of 'Englishness.'

The imagery used by journalists to describe action on the pitch involving England does reflect notions of warfare and includes but also goes beyond the simplistic clichés of football being a 'battle' between 'enemies' which Hopcraft notes are encouraged by the nature of the game itself. ${ }^{17}$ For instance, against Germany in the semi-final of Euro 96, England were 'Gallant' and played 'combative football' (The Times, 27 June 96) with McManaman being 'the flag bearer of [their] assaults' (ibid.). Individuals are, indeed, often singled out by British football writing as praiseworthy for their warlike leadership attributes. Platt, for example, in the match against Spain, was 'courageous' and 'heroic' (The Times, 24 June 96) while Adams 
was earlier described as 'the epitome of English footballing determination [who] made a rousing call to arms to his team-mates' (The Times, 8 June 96). Similarly, English players' actions in specific incidents are frequently portrayed by military metaphors: a pass by Sheringham in one game was said to be released 'as if out of a catapult' (The Times, 19 June 96).

As well as general references to warfare which illustrate the favoured virtues of the English stereotype, the data studied also provide examples of specific cultural references reflecting the same myths. For instance, the Times article reporting on the victory over Scotland may be cited: 'England's finest moment, never mind the hour, of Euro 96 has already taken place' (17 June 96) which, of course, evokes the famous 'this was their finest hour' segment from Churchill's 1940 Battle of Britain speech thereby situating England's performance on the football field in a socio-historical context of victory in warfare achieved by fighting spirit and the sheer will to win against a superior enemy. Indeed, the presence of the Churchill myth may be seen frequently in British football writing. One more example suffices: against Spain, England were 'always competitive' and distinguished by 'their own absolute refusal to surrender to what appeared to be a better team' (The Times, 24 June 96).

A second but, in the light of the above discussion, not entirely unrelated myth reiterated by the football writing studied is that of the brave Englishman totally committed to his cause: the patriotic lionheart. The lion as a symbol was thrust into prominence by the reign of Richard I, nicknamed the lionheart, whose heraldic arms of the three lions became an English national emblem and now, of course, appear as such on the shirts of the England football team. Richard's military exploits on the Third Crusade made him a mediæval legend which his death in battle against the French did much to enhance. ${ }^{18} \mathrm{He}$ was the prototype brave, courageous English lionheart who provides the implicit model for football journalists reporting on the England team's exploits. Against Germany, for instance, England benefited from the presence of 'young lions such as McManaman, Anderton, Barmby' (The Times, 27 June 96) while, earlier, Adams was 'the lionheart ... diving in with a tackle' (The Times, 24 June 96) and Shearer 'a lionheart in the English mould of Lofthouse, Milburn, Smith' (The Times, 19 June 96). Collectively, too, the English team's perceived qualities are often portrayed by this metaphor. Against Holland 'the lions were rampant' as 'England roar into the quarter-finals' (The Times, 19 June 96). 
The stereotype of Germany in the British football press is no less well defined than that of England and is based on three characteristics: strength, efficiency, and self-belief.

The myth of German strength and aggression is largely conveyed by military metaphors usually evoking Germany's rôle in the two world wars. Indeed, references to warfare are probably much more extensively made in media discourse when describing Germany than any other team, England included, and serve, therefore, to reinforce the belligerent image of the Germans which has been circulating in many cultural arenas, such as cartoons and political satire, since the late nineteenth century representations of Bismarck as the militaristic Prussian bully. ${ }^{19}$ Players representing 'the mighty Germany' (The Times, 24 June 96, 1 July 96) make 'sorties' (The Times, 20 June 96) and 'forays' (The Times, 25 June 96); they lead 'the battle on two fronts' (ibid.) and are suspected of preparing an 'ambush' (ibid.) for their opponents. Collectively, they 'regroup' (The Times, 3 June 96, 20 June 96), 'march on' (The Times, 20 June 96) and ensure their defence is 'a hostile zone' (ibid.). In one game, 'Germany were the first to advance, pressing the Czechs back with eight men garrisoned around their penalty box' (The Times, 29 June 96). Ultimately, their striker, Klinsmann, 'the blond bomber' will help them 'to conquer Europe' (The Times, 3 June 96). Even the footballer's career hazard of injury is conveyed in military terms when it befalls Germans: injured players are 'German wounded' (The Times, 24 June 96) and, with several players injured before the final, they obtained permission to 'draft reinforcements into their squad' (The Times, 29 June 96). In short, Germany's mythic strength is conveyed in politico-military terminology: it was quite simply 'the world's leading football power' (The Times, 2 July 96).

Second, but just as apparent in the data, is the stereotype of German efficiency which, partially at least, derives from widely-held appreciations of the post-war German economic miracle. German reconstruction after the war was swift and impressive, resulting in the German economy becoming the third strongest in the world and something of a model of economic efficiency for her European partners. In this context, the imagery in the British press constantly evokes machinery, especially automotive machinery with which the modern German economy is inextricably identified. One can, it seems, 'always rely on Germany' (The Times, 10 June 96), whose 'traditional efficiency should win them the title' (The Times, 27 June 96), because Germany 'is a tournament machine' (The Times, 2 July 96). The game 
against Russia provides further examples: 'Germany went about their business in the usual systematic way'; Hässler and Möller were 'a couple of midfield motorcycles who take the shortest line between them, their front-runners ... and the goal' and the German team as a whole 'typically looks as if it was manufactured in a factory by Porsche' (The Times, 17 June 96).

Finally, the notion of German self-belief is also perpetuated by British football writing. One of the reasons Germany won the tournament was, apparently, their 'belief, bordering on arrogant self-assertion that binds [them] again and again' (The Times, 2 July 96). Their striker, Klinsmann, was singled out as 'No one exemplifies [the German approach] more admirably' with his 'unremitting competitiveness ..., toughness of attitude' and 'battler's mentality' (The Times, 20 June 96). Similarly but more generally, to beat Russia the Germans 'drew on their collective resolve' (The $\underline{\text { Times, }} 17$ June 96) and the semi-final encounter with England (a nation with its own brand of spirit and commitment as we have seen) was won because Germany produced 'the competitive spirit that runs through the history of games between the nations' and displayed 'the conditioning and courage one expects from them' (The Times, 27 June 96).

With regard to France, one of the persistent myths reiterated by the British press is that of French flair. As Andrew Marr noted recently in The Observer, 'For most of British history, the educated middle classes have looked to France as a place where they live better' (20 February 2000). This notion, based on British (and French) appreciations of Gallic culture, cuisine and life style, is translated into sports media discourse by portrayals of France as a country where they play better, that is with fine technique and admirable style. As Euro 96 progressed, then, the French were said 'to delight with their positive attitude' (The Times, 19 June 96), particularly against Spain and Bulgaria around whom they '[danced] carefully crafted rings' (The Times, 28 June 96). Notions of spectacle and the performance arts are frequently evoked by the highly visual imagery used to describe French players. Djorkaeff was 'dazzling' and 'electrifying' against Spain (The Times, 19 June 96) while the same player's near miss against the Czechs provided an 'incandescent moment' (The Times, 27 June 96). The French team collectively is similarly described as 'alight' against Spain specifically (The Times, 19 June 96) and 'dazzling in the group games' in general (The Times, 1 July 96). The reason this promising team did not reach the final of the tournament is one often offered by British sports media discourse on the French: 
ultimately 'They could not generate the flair expected of them' (The Times, 27 June 96) and, in the nearest a British 'quality' newspaper gets to the punning so prevalent in the tabloids, they, therefore, lost their 'reputation for flair play' (ibid.).

On closer examination, this explanation of France's inability to qualify for the final recycles the second element of that country's stereotype in both British and French football writing: a lack of self-belief, the historical origins of which both Holt and Wahl trace to French military defeats at the hands of stronger, better organised (especially English and German) opponents. ${ }^{20}$ In the knockout stages, the French could not play with their supposed earlier flair because of this fatal flaw. Following the Holland match, for instance, The Times noted: 'If they possessed a belief to match their talents, they would have won comfortably and be strong favourites to win the European Championship' (24 June 96). The report then asked: 'If they can somehow start to believe ... who knows what may be possible?' (Ibid.). Worse was to follow after the semi-final defeat: under the headline 'France freeze in sight of Wembley' (The Times, 27 June 96), we read that the team 'seized up' and gave a performance marred by 'anxiety' and 'fretfulness' (ibid.). Rather than focus on the players' tactics or the misfortune of the penalty shoot out, the combination of which surely led to the French defeat, the reports analysed prefer to re-present the myth of the fragile French psyche. This was a 'fear-tainted' and 'inhibited performance' by the French who could not cope with the 'pressure of the unknown' (The Times, 28 June 96) and who ultimately 'succumbed once more to that affliction which seems always to grip them at major championships, a lack of belief' (The Times, 1 July 96).

The extent to which the British traditionally view the Spanish may be gleaned by examining the ways in which the British football press report on the Spanish national team. The Spanish are a temperamental team who 'lack ... ambition' (The Times, 19 June 96), and went into the England match suffering 'pre-match anxiety' as they were 'the side with more to fear' (The Times, 22 June 96). Paradoxically stereotypes are often paradoxical - the Spanish team's apparent strength and will power also feature in the articles analysed: 'Spanish defences are always hard' (The Times, 19 June 96), 'The Spaniards put up an almighty blockade' (The Times, 24 June 96), Nadal was 'ferocious' (The Times, 21 June 96), a 'hit man' (The Times, 22 June 96), Hierro 'the personification of his team in sheer physical presence and power' (The Times, 19 June 96) and Abelardo was 'violent' (The Times, 24 June 96). Predictably, too, there were references to the 'Spanish armada' (The Times, 19 June 
96) and 'the cut and thrust ... found in a bull ring' (The Times, 24 June 96). The last reference is a reminder that Spain is often perceived as a cruel country and the physicality of its team is portrayed as harsh and negative: they are uncompromisingly tough', 'England's most difficult hurdle', 'tenacious in their negative objectives' (The Times, 22 June 96). This often paradoxical imagery combines two contrasting elements of Spain's identity: the unpredictable Latinate temperament associated particularly with southern Spain which cohabits uneasily with the more spirited, less subtle approaches of northerners such as the Basques.

Finally, there is, indeed, awareness that Spain is a composite of different nations but this analysis goes no further than recycling stereotypes about those nations. Clemente, the then manager, is referred to as the 'feisty little man from the Basque Country' (ibid.) whose team, 'harshly organised in the uncompromising Basque tradition' (The Times, 10 June 96), contains 'tough northerners' who play with 'the fighting spirit of the British' rather than 'the individualistic flair' of other Latin countries (The Times, 22 June 96).

\section{National Representation in Spanish Football Writing}

Spanish football writing on England is characterised by the recurrence of several themes, many of which reflect the stereotypes the Spanish have of the English. First, there are conflicting images of the English as both 'gentlemen' and 'hooligans'. The English within the football context are portrayed as 'trouble-makers' ( $\underline{\mathrm{ABC}}, 8 \mathrm{June}$ 96) and as 'violent hooligans' (ABC, 9 June 96). Although comments are made on how English fans have changed over the last decade, these references are brief, occurring only within articles devoted to the discussion of the hooligan element of English support (스, 8 June 96; El País, 9 June 96).

Yet contrasting with this image of the English is that of the "Gentlemen who watch the match from their bars in London' (ABC, 27 June 96). And 'As the hooligans wreck London after the English lose to Germany, the England team win the UEFA fair-play award yet again' (ibid.). Although labelled as aggressive hooligans, in contradiction, when Londoners rejoice after beating Holland resoundingly they are described as 'resuscitated from their usual lethargic state' ( $\underline{\mathrm{ABC}}, 27$ June 96) and this Spanish image of the boring Englishman, tucked up in bed at eleven o'clock ( $\underline{\mathrm{ABC}}, 14$ 
June 96) is another which occurs throughout the data as frequently as references to fish and chips and cricket!

According to the Spanish press, English football is anachronistic, like its people who are perceived to continue to wallow in the successes of colonial supremacy. The English style of play remained unchanged while the rest of Europe developed new techniques: 'It remains anchored in its past' (El País, 6 June 96); 'Football returns to its birthplace ... to its origins ... Football's returning home' ( $\underline{\mathrm{ABC}}$, 8 June 96). The English are also seen as outsiders and are portrayed as such. Here the football reporting reflects the popular image held by the Spanish of the English as being geographically and politically isolated from the rest of Europe, a view seemingly supported by British governments' apparent reluctance to enter wholeheartedly into European political and economic union. The English are different from the rest of Europe. For example, '[The English] are used to less hysterical refereeing than Europeans' (El País, 13 June 96) implying that the English are not Europeans.

Another theme which reflects the Spanish preoccupation concerning England is that of the weather. It is clear that rain is expected as the norm. So when it rains reports begin, 'It was raining. Well, it is England' ( $\underline{A B C}, 8$ June 96). When it is 'unexpectedly' hot later in the tournament, it is the England team who will not be able to adjust to the weather and, despite the fact that the matches are taking place in England, 'The Mediterranean teams will have an advantage because they're more used to the heat' (ibid.). The temptation to stereotype the English weather, even when reality contradicts the image, is too irresistible for the Spanish press. There is no reevaluation of the original stereotype, which might be expected when reality clashes with the preconception, and the reader is left with a reinforced stereotype rather than its dilution.

The Spanish press displays great respect for French football which is reputed for its teamwork rather than for performances of individuals. Their open and flowing style of play is seen as part of the French character as perceived by the Spanish and, therefore, revolves around concepts of flair similar to those encountered in the British press: 'The French model works mainly because it remains faithful to its origins, a sort of genetic code which equates its footballers with good football, æsthetically pleasing football. It's a country which has maintained its identity' (El País, 6 June 96). Indeed, when the Czech Republic tried to prevent the French from playing with their usual flair, the Czechs were referred to as 'anti-football' ( $\underline{\mathrm{ABC}}, 27 \mathrm{June} 96)$. 
One aspect the Spanish press reported in a way which is not mirrored in the press of the other countries is the coverage of the number of France's black players. This theme is mentioned in the French press itself but only to report on Jean Marie Le Pen's criticism of 'foreigners' who do not know the words of the national anthem being selected for the national team (Le Monde, 25 June 96) and also in the German press, where it is portrayed positively as an example of France's successful multicultural society. In the Spanish press, however, the reaction is rather different. France's black players inspire a range of (often racist) remarks as the French team is compared to Cameroon of the 1990 World Cup and Nigeria of the 1994 World Cup 'except with the Latin instinct' ( $\underline{A B C}, 12$ June 96). 'Africans play a naïve style of football, take true pleasure in playing and the support is fanatical' is just one comment made of the French team. This report ends in a less than subtle reference to the colour of some of the French players: 'I'd like to see Spain beat France, but I see that as being difficult. I see black' (ibid.).

The stereotypes of the French reflected in the Spanish press, therefore, are as contradictory as the English images. Whilst on the one hand French footballing style reflects the very essence of what it means to be French, and this identity is neverchanging, on the other hand, the black players are seen as adding a new and different dimension to French football, surely then affecting the unchanging nature of the French way of playing. There is no attempt to reconcile these contrasting images.

Stereotypes of the German character pervade all references to the German football team and the images portrayed in Spain replicate to some extent those offered in the press in Britain. The same themes of strength, efficiency and self-belief are evident. Reports refer to the Germans' 'machine-like efficiency', their 'domination', and are replete with military metaphors, for example, when 'Vogts became serious his troops stepped into motion and began to dominate ... Then the Teutonic machine began to work' ( $\underline{\mathrm{ABC}}, 10$ June 96); '[We expect Germany] to come out and dictate the game to the Czechs.' (El País, 9 June 96). The team is credited with 'Order, control, sangfroid' (El País, 27 June 96).

Spanish football writing differs just in one aspect from that of the rest of the data. Underlying the British (and French) reporting it is possible to sense a certain (sometimes begrudging) admiration. In the Spanish press, however, there is little trace of this respect. Perhaps the fact that Spain places such value on style of play rather than on results accounts for their attitude towards the Germans. It is more important 
for Spanish sides to play well, with high levels of skill and flair, than it is to win. Boring football is not lauded, no matter how effective it is. ${ }^{21}$ Derogatory terms are employed at every opportunity and little credit is given for German victories. Selfbelief becomes simple arrogance. '[The Germans] played without concerning themselves with their rivals, and their pride in only thinking about themselves allowed the Czechs to create some problems for a while' ( $\underline{A B C}, 10$ June 96). The German players are denigrated as being 'workhorses ... who cover a lot of ground but play little football' ( $\underline{\mathrm{ABC}}, 27$ June 96). 'They usually get results they don't deserve' (El País, 6 June 96). Even towards the end of the tournament, which Germany won, they are described as, 'Consistent, rudimentary, granite-like, competitive, strong, brave, resistant. This time at Wembley. Germans, the same as ever ... Boring, monotonous. In short, Germany.' (El País, 28 June 96).

As with the English and French stereotypes, the images found in Spanish autotypification are contradictory. Beginning with the previews of the competition there is evidence of the Spanish lack of self-belief as they begin to make excuses for poor performances before a ball is kicked. This is reflected via continual comments on how tired the players are after a long season and the frequent use of phrases such as 'the long season', 'fatigue', 'physical and mental tiredness' (스C, 8 June 96). There are references to 'nerves', 'reservations' and 'fears'. Even manager Javier Clemente referred to his players as 'burnt out' ( $\underline{\mathrm{ABC}}, 9$ June 96). Yet concurrently, the Spanish texts reflect a contrasting optimism and attempt to display some self-confidence. The newspapers refer to Spain as 'favourites' and before Spain's first match against Bulgaria, the opposition is referred to as 'a difficult side, but within Spain's reach' (ibid.). A sense of insecurity is masked on occasions by pronouncing self-belief. Here it is reflected by making excuses before the event in case of failure. Perhaps the Spanish mentality is best reflected in one quotation from El País: 'The enemy is the team, and its fear of success.' (6 June 96).

Some of the divisions which have their origins in historical and political developments within Spain and which are evident in domestic match reports ${ }^{22}$ resurface in reference to the national team. The affiliation of the nacionalidades históricas of Catalunya and the Basque Country are questioned. Before the Bulgaria match Stoichkov (then of FC Barcelona) opened the debate declaring, 'Catalans want Bulgaria to beat Spain', to which Clemente responded, 'Since there are four Catalans 
in the national side, this is unlikely. Besides, there are many Catalans who like Spain' ( $\underline{A B C}, 9$ June 96). Thus, the polemic ensued for several days.

Spain's former manager himself was a key figure in Spanish football writing. The Spanish press did not let its readers forget that he is Basque. Clemente himself stated: 'At least $80 \%$ of the time I'm referred to as Basque is when I'm being criticised. If I select Basque players no one discusses how good they are, they just comment on the fact that they are Basque.' (El País, 2 June 96). In addition, the Basque stereotypes of physical strength and courage pervade all references to the Spanish style of play. 'All [Clemente] wants is for Spain to battle hard' (ibid.). Spain are described as playing 'fast and furious', 'whole-heartedly', with 'Spanish fury', 'a physical style of football, sacrificial, instinctive, British in style with a hint of Latin spirit' (El País, 6 June 96). Comparisons with the English serve only to reinforce the Basque association within Spanish football as it is widely known in Spain that football in the Basque Country was introduced by the English and the Basque style of play has historically been closely associated with the English physical style and directness (long balls played to a big centre-forward). ${ }^{23}$ Clemente even describes Spain as 'More English than the English' and after losing to England claimed, 'Spain was the best English team on the pitch.' (El País, 23 June 96).

\section{National Representation in French Football Writing}

The French self-image reflected by football writing in Le Monde and Libération is made up of three elements. The first perception is that style is, or should be, a typical French trademark. As with the British press coverage, French players' qualities are often described using visual imagery and the vocabulary of the performing arts. Pedros, for instance, was 'alight' in one game (Libération, 20 June 96) while Karembeu was an 'artist' in another (Libération, 19 June 96). Similarly, squad members waiting for their chance to play were described in the language of the cinema by Le Monde (26 June 96) as 'extras' implying that the first team are the stars of the show which is French football while the same paper remarked that the disadvantage of having such a good defence is that the goalkeeper, Lama, has not been given the chance 'to shine' (25 June 96). French players themselves also contributed to the shaping of this myth. Before the crucial Bulgaria game, Deschamps was quoted as saying 'shutting up shop is not our style' (Libération, 18 June 96) 
while, after the match, Karembeu declared himself pleased with the result (a 3-1 victory) but not with the style in which it was obtained (Libération, 19 June 96). Indeed, French teams are castigated in football writing (on both sides of the English Channel) if it appears they are not playing with their supposedly typical flair. Le Monde (18 June 96), for example, bemoaned the overly defensive formation adopted by France as it prevented midfielders like Zidane from expressing themselves creatively and the same paper hoped, after France's exit from the tournament, that the team competing in the 1998 World Cup would produce 'a more attractive spectacle than that ... offered over the three weeks in England' (29 June 96). Even the former national team captain and manager, Platini, felt compelled to evaluate the French performance as 'good from the point of view of results' but 'the solid performance can be only a starting point, a base on which to build a certain style' (Le Monde, 30 June 96).

The second element in French autotypification through football writing is ostensibly similar to other countries' views of themselves as warrior nations. The specificity of the French case, however, lies in the detail of the language used in the imagery in question which evokes socio-historical references which are uniquely French. Beyond the simplistic clichés of football matches being 'a battle' (Libération, 10 June 96) in which the 'French troops' (Le Monde, 25 June 96) have to 'close ranks' (Libération, 18 June 96), lie images of the French people as victims of aggression rising to rectify past injustices by taking revenge on the barbaric aggressor, images which, in the French mind, connect with events such as Joan of Arc's leading of the rise against the English in the Hundred Years War, the wars waged by the French Revolution to repel invasions by anti-democratic neighbours and the 1914-18 campaign to retrieve the 'lost provinces' of Alsace-Lorraine annexed by the Germans in 1871. For example, Le Monde's preview of the Bulgaria match (18 June 96) contained an emotional appeal 'To arms!' (replicating the first segment of the refrain of the Marseillaise, the French national anthem adopted during the Revolution: 'To arms, citizens!'). The Bulgarians were portrayed as 'the villains of the piece' who want 'to harm [France]' and upon whom 'revenge' must be taken for the night in November 1993 when Bulgaria became not only the last team to beat France but also the team which knocked them out of the World Cup. Libération similarly evoked the concept of revenge speaking of 'a wrong to be put right' and the memory of 'a national crisis [the 1993 encounter] to be effaced' (20 June 96). Moreover, the 
Bulgarian opponents are demonised by the media discourse employed: rather than be seen specifically as footballers or even generally as human beings, they become inhuman 'phantoms', barbaric 'demons' who are obstructing French progress (Le Monde, 20 June 96).

The final element in the French sporting stereotype communicated by the texts studied concerns the perceived psychology of the nation itself. The morale of the French is often qualified as shaky with the team lacking the 'typically German' quality of self-belief (Le Monde, 28 June 96). Le Monde, for instance, was concerned that the French team 'does not really know how far it can go' (14 June 96) and later ascribed its defeat in the semi-final to its lack of mental strength and will power (28 June 96). In French eyes, this 'inability to win at the highest level' (Le Monde, 28 June 96) was partly a result of fear of failure which was itself fuelled by memories of previous defeats. The victory over Bulgaria, for example, was heralded not only as welcome revenge for a previous defeat but also as a victory 'over ourselves, over our own obsessions' and as an exorcism, laying to rest the 'ghost' of the past (Le Monde, 20 June 96).

The image of England represented by the French press articles studied is similar to that found in England itself in one respect, the physical strength of English players, but differs somewhat in two others.

England's apparent lack of flair is often criticised in French football writing (e.g. Le Monde, 11 June 96) but due acknowledgement is also usually given to the positive side of the English stereotype: England win, apparently, because of their great physical strength, passion, and commitment, traits which we have already seen lauded by the British press itself. The victory over Holland, for instance, ensued because 'the Dutch collapsed in the face of English energy' (Libération, 20 June 96). For the French, it is English and German teams which personify the virtues of physical and mental strength, energy and sheer power. The semi-final between England and Germany, therefore, proved too good an opportunity to miss for the representation of such stereotypes: this was another in a line of 'Anglo-German football wars' (Le Monde, 29 June 96) in which the Germans resisted 'the searing offensive' and 'brave charges' of their opponents who were full of 'English zeal' (ibid.). The myths of English and German power are clearly kept intact by such discourse. 
The second element in the myth of the English as seen by the French relates to Britain's political status as a monarchy. Frequently the England team is referred to in the French media as 'Her Majesty’s players' (Libération, 10 June 96) and English supporters are described as 'the monarch's subjects' (Le Monde, 20 June 96). Interestingly, though, despite the fact that the monarchy is a British institution rather than a solely English phenomenon, these royal motifs are rarely if ever associated by French media discourse with the other three constituent countries of the United Kingdom, rather they cluster around the England team.

Finally, we note in French football writing another trait which might be considered part of a wider English identity as perceived by the French: psychological inhibition. England, in this stereotype, is a land of tradition, afraid to step into the modern world and break with the past and the England football team personifies this refusal to acknowledge progress. England's reputation in French football circles has, until recently, been one of arrogance born of insularity and a snobbish rejection of innovation, particularly from abroad. ${ }^{24}$ 'Football here', then, 'is a nostalgia business' (Le Monde, 25 June 96). England is ‘tied to its memories' (ibid.) constantly reliving its past glories. This country is too bound to tradition to modernise successfully: 'The years and the tournaments come and go, nothing changes in the home of football' (Le Monde, 11 June 96). The English 'put all their heart into respecting traditions which have no more to commend them than does that of high tea' (ibid.). To focus the stereotype even more sharply, the newspaper contrasts England with Holland, their main group rivals. The Dutch, open minded, experimental, inventive modernisers, represent 'the continental antithesis of British obsessions' (ibid.). Ironically, England beat Holland 4-1 with a performance prompting the comment: 'the English have got rid of their inhibitions' (Le Monde, 20 June 96). However, the very next sentence in the report qualifies this adventurous statement with 'Or rather they have clothed their traditions with one or two last minute novelties' (ibid.). This example illustrates a mechanism prevalent in stereotypification. When the evidence suggests the stereotype is inaccurate (as here when England played with supposedly un-English style), then the evidence itself is moulded by media discourse to fit the preconceived image even at the risk of setting up contradictions, inconsistencies, or discursive incoherence (here the flair England displayed to beat the Dutch is merely an after thought, an additional element to the traditional virtues of stout defence and energetic work rate). 
The French perception of German identity as reflected in football writing replicates almost exactly, element for element, the German stereotype already encountered in the British and Spanish press.

First, the Germans are a strong, powerful but aggressive people. To add to the examples from the coverage of the England-Germany game, we note that in Euro 96 the Germans displayed ‘tonnes of muscle and determination' (Le Monde, 18 June 96) and a characteristically 'hard-hitting style' (Libération, 10 June 96). It was in the group game against the Czechs that these attributes were foregrounded by the press articles studied: here the Germans 'flexed their muscles' catching the 'physically inferior' Czechs in a deadly 'German pincer grip' (ibid.). With the same teams about

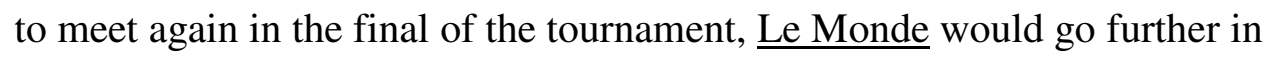
reconstructing the stereotype of the aggressive German. In its preview, it presented Vogts, Germany's manager, as the personification of his team and his nation: 'It is difficult to find anyone more German than Berti Vogts [who] is the incarnation of German football's strength and success' (Le Monde, 30 June 96). Moreover, the article from which this extract is taken appears immediately alongside a piece on the history of German-Czech diplomatic relations which ostensibly seems out of place on the sports pages. However, by evoking memories of the German invasion of Czech territory in 1939, raising the spectre of German economic imperialism there in the 1990s and juxtaposing these to a football match preview, the media discourse implies that not only is football an extension of society, an arena into which nations' political and diplomatic relationships are carried but also that the rôle of the Germans is always to be the aggressor. Having portrayed the Germans as aggressors in the preview, the same newspaper's report of their ultimate victory employs familiar imagery to complete the construction of the stereotype: 'nothing stopped their march ... when the time came to make the kill, they did not hesitate, relishing their rôle as assassins' (Le Monde, 2 July 96).

Confidence and self-assurance are also presented as typical German traits by the French football reports analysed. Belief in ultimate victory is, apparently, something which is 'rooted deeply in the German players' (Le Monde, 28 June 96). Even when playing against that other totally committed nation, England, 'Nothing could shake the German team's confidence ... Not once did a German player tremble' (Le Monde, 28 June 96). 
To complete the picture of Germany painted by French football writing, we observe the same representation of technical efficiency as found in British and Spanish texts. Previewing the Italy game, Libération (19 June 96) noted the 'rigour' and 'practicality' of the German team which is 'never spectacular but maddeningly efficient and disciplined' and described one of its players, Eilts, in mechanical terms as the 'pressure regulator' moving up or down the field to adjust the team's overall balance. To French eyes conditioned by media representations of flair and style as necessary accompaniments to sporting endeavour, ${ }^{25}$ this 'fine Germanic order' (Le $\underline{\text { Monde, }} 21$ June 96) is not all that æsthetically pleasing. Indeed, Le Monde asserts that in a tournament which was generally 'dull', the Germans, being dull themselves, were 'the most appropriate winners' (2 July 96). However, there remains a begrudging admiration in France for the Germans who, despite their aggressive and dour reputation, are still regarded as ‘a model nation' (Libération, 21 June 96).

\section{National Representation in German Football Writing}

Much can be understood about Germany's self-image by examining the reaction of the

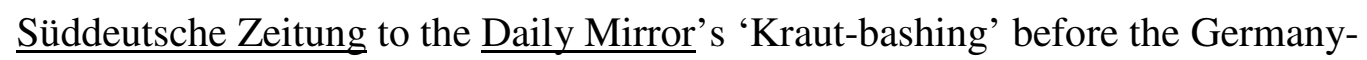
England semi-final. The British tabloid carried the headline 'Achtung Surrender!' supported by text asserting 'For you, Fritz, ze Euro 96 Championship is over' and a picture of England players Paul Gascoigne and Stuart Pearce sporting superimposed army helmets (24 June 96). The whole, replete with further crude references to the second world war, prompted widespread criticism of its jingoistic and xenophobic approach to the Germans in the context of what was supposed to be, after all, an amicable sporting contest. ${ }^{26}$ A correspondent from England wrote to the German newspaper apologising for the Mirror's behaviour. The Süddeutsche Zeitung accepted the apologies, but far from agreeing with the correspondent and all those indignant newspapers which stressed the Mirror's bad taste and the importance of AngloGerman relations, it sided with the Mirror. It accepted 'Kraut-bashing' as a British national pastime, like cricket, greyhound racing, darts and bingo - all of these are certainly strange to Germans, but since they originate in the mother country of sport, it must be all right. The Mirror's contribution was seen as a piece of real life satire, an example of the British sense of humour, which, according to Germany's manager, Vogts, the Germans 'know well' (Süddeutsche Zeitung, 26 June 96). The Süddeutsche 
Zeitung even felt sorry for the Mirror, which had now to endure so much criticism in turn, although the writers of that paper should be considered 'humorists'. How easy it would have been for the German newspapers to exploit this situation, to show moral outrage and, as the injured party, acquire some moral kudos from it. But the opposite occurs. It is as if the Germans recognise themselves in all these moral, politically correct condemnations by the high-brow press and well meaning citizens, their highly principled assurances that these views on Germany are not shared by the majority, and especially in Bobby Charlton's confession of 'shame', with which he trespassed onto German territory, since this part is usually played by the 'good', repentant Germans who have to bear the guilt stemming from the previous generation's involvement in the second world war. It seems the German newspaper enjoys the incorrectness and frivolity of the British press, something which German public discourse is so badly lacking, and which therefore can be found and appreciated only outside Germany. It is the lack of comic relief from which the Germans suffer and for which England is so well known, liked and admired. Any remorse and earnestness from the English, then, is something genuinely disappointing for the Süddeutsche Zeitung.

Other interesting conclusions regarding German autotypification can be drawn from the reports of the Italy-Germany match. Since the corresponding match in Mexico in 1970 (labelled in the international press the 'match of the century'), every meeting of these teams raises high expectations and gives observers the opportunity to comment on the current state of German affairs. The match in Mexico was the start of the best, most elegant, most stylish and adventurous football Germany has ever played. It was coincidentally also the beginning of the social-liberal era, a period full of optimism, promises and willingness to reform on all fronts. It was also when Germany's international image improved considerably, which was simultaneously achieved on the football pitch and in the political arena. Germany genuinely started to liberate itself from its history, the continuity of the Nazi mentality and an administration which was based in the past. Twenty six years later, where did Germany stand? During his term of office (1982-1998), Chancellor Kohl's main strength was to continue what he had done before: 'Continue as before, Germany', was one of his successful electoral slogans. His other forte was to sit out any crisis he encountered (and there were many). Whatever negative thing could have been said about Kohl (mainly lack of vision), there was always one thing which justified everything he did: success. It was very appropriately reported therefore that Kohl 
congratulated Vogts, his friend, after the dull, defensive performance against Italy by speaking of the German team's 'super performance' and adding: 'It's not important how one wins but that one wins', thereby justifying his own policy with the help of the people's game and revitalising one of football's most contentious formulæ (Suiddeutsche Zeitung, 21 June 96). The Süddeutsche Zeitung in this instance views political history and football together. The strategy in both appears the same: save your skin, regardless of the costs.

It is not that the Germans have not tried to shed this image of the dull, efficient and often undeservedly lucky team. Like the New Germany they have been keen to make friends and to please. Only two years before the European Championship Vogts postulated that he would rather die beautifully than win in bad style (ibid.), but all too readily the Germans are portrayed as reverting to their old ways which is playing defensively and trying to destroy whatever is creative in the other team's game.

The German team has to be represented as one without stars. 'Der brave Eilts' (Süddeutsche Zeitung, 17 June 96) - the 'upright, worthy, honest' Eilts - that is the description of the Süddeutsche Zeitung for the man who became the (anti-)star of the German team, the personification of its dominant values: fight, tackle and run. 'Der brave Eilts', this is an adjective which alludes deliberately to the 1950s, where all the players (except for Rahn maybe) could be described as good and well-behaved. ${ }^{27}$ Is this a hint that post-unification Germany has a lot in common with the post-1945 Germany? Is this a confirmation of Kohl's status as 'Adenauer's grandson'? Does the Süddeutsche Zeitung think that Adenauer's slogan 'no experiments' applies equally well to the New Germany? The other uncharismatic 'star' of the German team was Oliver Bierhoff. He is described by the Suiddeutsche Zeitung as typically 'petitbourgeois', emotionally constipated, rational, unspontaneous and even after victory in the final only cautiously enthusiastic (Süddeutsche Zeitung, 2 July 96), again confirming the most common stereotype of the German: boring, but efficient.

Another article (21 June 96) refers to the Germans as dull and unimaginative, sending home the Italian team whose manager was a 'visionary'. This example shows how print media discourse on football reflects the dominant values of the time: there is no space for vision, experimentation or playfulness, it is all about success no matter what and here, indeed, the Germans are champions.

It is clear from these examples how critical Germany is of itself (through the eyes of the liberal press). The stereotypes other nations have of the Germans are 
confirmed. The total absence of any war vocabulary is interesting, though. This is a luxury the Germans, for obvious reasons, cannot enjoy. Instead we get fine irony which undermines any attempt at self-glorification.

As for the French, the Süddeutsche Zeitung presents them as being 'liberated from their own complexes', as self-confident, and as having lost their own self-doubts (12 June 96). Jacquet, the manager, is a cool strategist, and the game has to be played only one way: 'perfectly' (ibid.). Individualism is not encouraged but rather team spirit and harmony are stressed. Players like Ginola were not needed because they were seen as 'too unpredictable' (10 June 96). France appears as a mixture of technical brilliance, cool tactics, hard work and perfect defensive play (12 June 96). It is not only technical brilliance as there is also Desailly who 'clears up' at the back with the 'force of a bulldozer' (ibid.). France's defence is a 'unified front with the necessary luck' (19 June 96). Self-confidence and luck are, then, two characteristics employed by the Süddeutsche Zeitung for the French. Altogether the description of the French is cool, self-confident but ultimately disappointing. The French are certainly not allotted a special status as the English are. Maybe they are too close in many ways to the Germans, as the descriptions above show. Great interest was shown in the multi-racial aspect of the French team, though, something totally absent from the German squad, and especially the way in which its black players dealt with hostility from the extreme-right in their own country.

For the Süddeutsche Zeitung England is 'football's spiritual home', the place where it all began and where football is an essential part of everyday life. In the commentaries on England there are constant references to the past, the great nation of the past is contrasted with its present state. At the same time there is some sympathy for the English. After the bad start against Switzerland, German striker Klinsmann was one of the experts called up to vouch for England's good performances in future games. The Germans clearly like England to be successful (Süddeutsche Zeitung, 10 June 96). England can also be represented as a backward, conservative country in the German press (as it is in the Spanish and French press) where 'punchy slogans are still suitable today' (ibid.). The slogan in question being The People's 'Stay cool and slaughter the Scots.' Also the playing style of the English is described as anachronistic. The players are seen as old-style fighters who jump 'with their elbows dangerously angled into the backs of defenders' (ㅎid.). In contrast, the good old times are evoked when England was the embodiment of fair play. The then manager Terry 
Venables is unfavourably compared to his predecessors (especially of course Sir Alf Ramsey): 'This mister is no gentleman, let alone a Sir' (ibid.).

England's lack of discipline, the players' involvement with drugs and alcohol is a recurrent theme. ${ }^{28}$ Paul Gascoigne's head at the beginning of the second half of the Switzerland match is compared to the colours of English beer bellies in the late afternoon of the first day of a holiday abroad (ibid.). For the Süddeutsche Zeitung Gascoigne is the personification of England's eccentricity and individualism, 'between genius and childishness' (ibid.). This is written in a mixture of disbelief and secret admiration. That a footballer can exhibit such disregard for nutritional matters as Gascoigne does is difficult to believe for German sports writers and yet how they long for a player who could exhibit such incorrect behaviour and still perform well.

'Footballs instead of bullets', the Süddeutsche Zeitung headlines its article on the Scotland-England match. The importance of the match between these teams is underlined by drawing on historical events, for example when the English slaughtered the army of Bonnie Prince Charles in 1746. Even after the victory was won, the soldiers of the English-Hanoverian king continued to kill defenceless Scottish victims. It was, therefore, no surprise that Bobby Charlton was quoted as explaining how much more important it is for the Scots to win than for the English. But still, a 'battle' it will be, albeit only a 'battle on the pitch.' The national myth is evoked according to which all Scots are united in their hatred of England, and all the fundamental regional, political and religious differences between the Scots themselves are forgotten.

When the English play badly, an unflattering comparison with the past is made: the grand old nation of football has sunk to mediocre status, and long gone are the days of gentlemanly behaviour; instead we have hooliganism and alcohol excesses on and off the pitch. When the English do well, however, the 'renaissance of the football nation' is announced (19 June 96), as in the Holland game. It is astounding how quickly the German perception of England changes as soon as they play elegantly and successfully. In the Switzerland match the characterisation of the English centred on violence and alcohol, while in the match against the Dutch the journalist goes into raptures about the technical superiority of the English. However he is not quite willing to drop the old stereotype and calls the imaginative passing of the English 'unusual'. The English 'metamorphosis from cart horses to thoroughbreds' was observed (20 June 96). Whilst in the Switzerland match they were a 'drunken bar troop', they are after the Holland match 'knights of the honorary 
legion' (ibid.). The Holland-England match report is headlined: 'Like a journey back to a more magnificent time.' After this match comparisons are made with the World Cup winning team of 1966 . 'Football has indeed returned to the country of its fathers, and since Tuesday the world knows where its cathedral lies. Under the white dome and the twin towers of Wembley Stadium. Everything exactly like 30 years ago.'

The image of the English portrayed in the Süddeutsche Zeitung, then, is contradictory: anachronistic and modern, cool and crazy, gentleman and hooligan, hard workers and drunks. But there is no doubt that German sympathies lie with the English. While the German fans are described as dull and remarkable only through their sheer numbers, the English fans are described as in a state of 'ecstasy' and 'hysteria' (24 June 96). There seems to be an unspoken prohibition in the liberal German press against too much enthusiasm for its own national team. Instead this is expressed by writing enthusiastically about other nations, notably England.

\section{Conclusion}

We have seen that the vocabulary and imagery used by European football writing to (re)construct national stereotypes is varied, entertaining and often highly inventive as well as occasionally provocative and inflammatory, evoking references to warfare (the Battle of Britain), politics (the administrative divisions of Spain), history (the French Revolution), economics (the German car industry) and popular culture (English beer bellies). Also two mechanisms at work in stereotypification have been identified. First, stereotypes may be paradoxical if not discursively incoherent (the English are hooligans and gentlemen, the Spanish fearful and strong minded); second, they frequently manipulate reality to make it fit preconceived notions thereby preserving European myths of national identity (style when displayed by English footballers is qualified as unusual because, in print media discourse on football - as in other social and cultural arenas - style is not an English trait but a French one).

It is also interesting to note that in most but not all cases, the principal elements of the stereotypes re-presented by the press in Europe's dominant football nations are essentially the same from country to country. The fighting spirit of English autotypification is replicated in French accounts and, with negative connotations, in Spanish and German print media sports texts which are also united in highlighting English fair play and gentlemanly conduct. Similarly, England's apparent obsession 
with tradition and the past is a theme found in Spain, France and Germany. Spain's image is of a tough, harsh and cruel nation. It is also contrary, at once pessimistic and optimistic, and divided by the different components of its politico-administrative make up. The European football writing studied is almost unanimous in its perception of the French. French style is reflected as artistic flair in Britain and in France itself, as a genetic inheritance in Spain, and as brilliant technique in Germany while both Spanish and German newspapers agree on the notion of France's fraternal teamwork ethic even if its multi-racial element is viewed negatively by the former and positively by the latter. The only divergent note in the data relating to France is sounded by the German texts which portray the French as confident whilst the French and British articles allege the opposite. The greatest convergence in perceptions of national identity is to be found when European football writing focuses on Germany. The British, Spanish and French texts all construct the German stereotype in the same terms: aggressive strength, dull efficiency and arrogant self-belief (although these attributes are almost admired in Britain and France but denigrated in Spain). Even German autotypification recognises most of these traits although here strength and success cannot, as elsewhere, be conveyed by military metaphors for obvious reasons. Similarly, self-belief cum arrogance is also absent from German perceptions of German identity. Instead German football writing is ironic and critical. Selfglorification and militarism are still taboo in public discourse in Germany but widely attributed to Germans by other Europeans.

It seems, then, that the rôle played by European print media discourse on football is to reinforce if not inculcate myths of national character which are rooted in wider politico-diplomatic and socio-economic objective realities. Football writing in Britain, Spain, France and Germany constantly plays the identity card and, in so doing, strengthens notions of collective identity generated by sport and media reflexions of sport. ${ }^{29}$ As Europeans, the one thing we can apparently all agree upon is precisely how we allegedly all differ from each other and, in this sense, football writing reflects the dominant culture of Europeans who are, it would appear, given the pervasive predilection for accentuating supposed differences in national character observed in our data, a long way from attaining a state of 'ever closer union'. 
Acknowledgement

We are grateful to Paul Darby for his patience and the many useful suggestions he made on an earlier version of this article.

Notes

1. L. Crolley, D. Hand and R. Jeutter, Imagined Identities? Football, Europe and the Press (London, Frank Cass, forthcoming).

2. By 1999, these countries along with Italy, which could not be covered here for reasons of time and space, had won eight World Cups and six European Championships while, at club level, teams based in them had won almost four fifths of all major European trophies contested. See E. Saccomano (ed.), Larousse du football (Paris, Larousse-Bordas, 1998) and Four Four Two (August 1999).

3. A. Hopcraft, The Football Man (London, Simon and Schuster Ltd, 1988), ch.7.

4. Ibid.

5. L. Crolley, D. Hand, and R. Jeutter, 'National obsessions and identities in football match reports', in A. Brown (ed.), Fanatics! Power, Identity and Fandom in Football (London, Routledge, 1998), pp.173-85.

6. N. Blain and R. Boyle, 'Sport as real life: media sport and culture', in A. Briggs and P. Cobley (eds), The Media: An Introduction (London, Longman, 1998), p.365.

7. Ibid., p.369.

8. Ibid., p.370.

9. A. Higson, 'National identity and the media', in Briggs and Cobley, The Media, p.354.

10. Ibid., p.356.

11. Ibid., p.360.

12. N. Blain, R. Boyle and H. O'Donnell, Sport and National Identity in the European

Media (Leicester, Leicester University Press, 1993), ch.4.

13. Ibid.

14. J.A. Mangan, 'Duty unto death: English masculinity in the age of the new imperialism', in J.A. Mangan, Tribal Identities. Nationalism, Europe, Sport (London, Frank Cass, 1996), p.12.

15. Ibid., p.18. 
16. Ibid., p.17.

17. Hopcraft, The Football Man, ch.7.

18. See A. Isaacs and J. Monk, The Illustrated Dictionary of British Heritage

(Cambridge, Market House, 1986), pp.370-1 and I.H. Evans, Brewer's Dictionary of

Phrase and Fable (London, Cassell, 1990), p.667.

19. BBC 2, Best of Enemies (12 January 2000), television programme (Kenneth

Baker, presenter; Alison Cahn, producer; Anne Tyerman, editor).

20. R. Holt, 'Contrasting nationalisms: sport, militarism and the unitary state in

Britain and France before 1914', in Mangan, Tribal Identities, pp.39-54; A. Wahl, Les

Archives du football. Sport et société en France (1880-1980), (Paris,

Gallimard/Julliard, 1989).

21. See Crolley, Hand and Jeutter, Imagined Identities?

22. Crolley, Hand, and Jeutter, 'National obsessions and identities', pp.183-84.

23. For more on the historical links between Spain and English football, see F.

Martialay and B. Salazar, Las grandes mentiras del fútbol español (Madrid: Fuerza

Nueva Editorial, 1997).

24. See Saccomano, Larousse du football, pp.214-15.

25. See Crolley, Hand and Jeutter, 'National obsessions and identities' and A.

Greaves, 'Sport in France', in M. Cook (ed.), French Culture since 1945 (London,

Longman, 1993), pp.130-32.

26. For further discussion of the incident and its repercussions, see J. Garland and M.

Rowe War minus the shooting? Jingoism, the English Press and Euro 96 (Leicester,

Scarman Centre, Crime, Order and Policing Series Occasional Paper no. 7, 1997) and

E. Poulton, 'Fighting Talk from the Press Corps' in M. Perryman (ed.), The Ingerland

Factor. Home Truths from Football (Edinburgh, Mainstream, 1999), pp. 119-35.

27. N. Seitz, Dopplepässe: Fußball und Politik (Frankfurt, Eichborn, 1997).

28. England players Paul Merson and Tony Adams had to overcome addictions to drugs and alcohol respectively while the entire team was criticised prior to Euro 96 for its rowdy behaviour on the aeroplane bringing them home after a tour of the Far East.

29. For more on football's rôle in this respect, see P. Boniface (ed.), Géopolitique du $\underline{\text { football (Brussels, Editions complexe, 1998); Crolley, Hand and Jeutter, Imagined }}$ Identities?; H. Dauncey and G. Hare (eds), France and the 1998 World Cup. The National Impact of a World Sporting Event (London, Frank Cass, 1999); Mangan, 
Tribal Identities; Perryman, The Ingerland Factor and J. Sugden and A. Tomlinson (eds), Hosts and Champions. Soccer Cultures, National Identities and the USA World Cup (Aldershot, Arena, 1994). 